\title{
APRESENTAÇÃO DO DOSSIÊ ASCENSÃO E QUEDA DO PARAÍSO TROPICAL
}

A imagem do Brasil como "paraíso tropical” tem uma longa história, como mostram os conhecidos estudos dos prestigiados intelectuais Gilberto Freyre e Sérgio Buarque de Holanda e, posteriormente, os trabalhos de Ronaldo Vainfas, de Ronald Raminelli e de Richard Parker, entre outros. ${ }^{1}$ Desde os inícios da colonização, apontam esses autores, os europeus perceberam os povos nativos como indolentes e preguiçosos, desrespeitando suas tradições e negando violentamente seus modos de existência. Não foi muito diferente a imagem que construíram dos negros e das negras africanos, aqui trazidos pelo tráfico negreiro para substituir o trabalho indígena, segundo a triste e nefasta imaginação cristã dos colonizadores europeus.

Sensualidade, docilidade, preguiça e irracionalidade foram atributos construídos pelo racismo estrutural para nomear negros/as e indígenas, no Brasil, o que vem sendo fortemente denunciado em nossos dias, por vários autores e autoras, desdobrando críticas profundas trazidas por pioneiras como Lélia Gonzalez e Suely Carneiro. Nos anos de 1990, Richard Parker estranhava a maneira pela qual os brasileiros se percebiam e não apenas eram percebidos, a partir da imagem da sensualidade à flor da pele. Assim, o antropólogo estadunidense questionava a imagem de "povo sensual" com que se viam ou eram vistos os brasileiros, assim como o mito da "democracia racial", que Thomas Skidmore denunciara, desde a década de 1960, seguido por muitos outros pesquisadores brasileiros e estrangeiros. ${ }^{2}$

Ainda assim, por muito tempo, o Brasil foi e talvez continue sendo visto como o país do carnaval, do samba, do corpo, da alegria, das "mulatas sensuais", em contraste com a rígida moralidade europeia e com o puritanismo estadunidense, o que implica conjuntamente a noção de irracionalidade e de incapacidade política de autogerir-se. Estultos, os brasileiros não se vinculariam fortemente à tradição e deixar-se-iam levar

1 FREYRE, G. Casa Grande e Senzala. 2. ed. Rio de Janeiro: Schmidt Editor, 1936; HOLANDA, S. B. de. Raízes do Brasil. 26. ed. Rio de Janeiro: José Olympio, 1994.; VAINFAS, R. Trópico dos pecados. Rio de Janeiro: Campus, 1989; RAMINELLI, R. Imagens da Colonização. A representação do índio de Caminha a Vieira. Rio de Janeiro: Zahar, 1996; PARKER, R. Corpos, Prazeres e Paixões. Rio de Janeiro: Editora Best-Seller, 1993.

2 SKIDMORE, T. Preto no Branco: Raça e Nacionalidade no Pensamento Brasileiro (1870-1930). São Paulo: Companhia das Letras, 2012. 
pelo vento, ficando à mercê dos acontecimentos imediatos, sem conseguirem definir um projeto próprio de vida em sociedade e de política, entre outras dimensões existenciais. Em consequência, entende-se que os brasileiros precisam continuamente ser conduzidos, e conduzidos por mãos firmes e fortes. A justificativa para a ditadura civil-militar ganhou forma nesses termos, na década de 1960, causando imensos prejuízos e destruições coletivas, individuais, físicas, emocionais e psíquicas, como sabemos hoje por uma ampla literatura de denúncia e pelo intenso trabalho de ativistas, de ex-presos/as políticos/as, de parentes, filhos ou amigos, preocupados em documentar e dar visibilidade às inúmeras formas de violência cometidas no período ditatorial, chegando ao extermínio físico de muitos opositores políticos e à eliminação de seus rastros corporais.

Em nossos dias, o mito do Paraíso Tropical e todas as representações imaginárias que o envolvem desmoronam rapidamente, à medida em que se acentuam tendências políticas, sociais e culturais profundamente retrógradas, misóginas e perversas, arraigadas em nossa cultura desde sempre, e que se fizeram notar mais explicitamente ao longo do período autoritário e durante o momento conhecido como redemocratização.

Mais recentemente, a pandemia que assolou o mundo acelerou o processo de desagregação social no Brasil, resultante da trágica situação política em que vivemos, desde a ascensão de grupos neofascistas ao poder e da escalada neoliberal. Sofisticadas análises têm atentado para a expansão da racionalidade neoliberal por todo o social, o que Wendy Brown, inspirada na crítica ao neoliberalismo realizada por Michel Foucault, em Nascimento da Biopolítica, denomina de "economização do social", ou extensão da lógica do mercado para se pensarem todas as dimensões da vida humana, inclusive nas relações afetivas e familiares. ${ }^{3}$

Sem dúvida alguma, já não temos como nos ver, nem sermos vistos, como o país paradisíaco e, muito pelo contrário, constatamos a violência crescente tanto nas formas de exploração do trabalho quanto no racismo e sexismo estruturais, que marcam fortemente as relações cotidianas, na opressão de gênero, na destruição das florestas e das matas, no genocídio que afeta as populações indígenas, negras, transexuais, pobres, periféricas e

3 BROWN, Wendy. Undoing the Demos: neoliberalism's stealth revolution. New York: Zone, 2015; FOUCAULT, Michel. Nascimento da Biopolítica. Curso dado no Collège de France (1978-1979). Tradução de Eduardo Brandão. São Paulo: Martins Fontes, 2008. 
na perseguição homofóbica às "minorias", em todo o país.

Assim sendo, tendo em vista discutir e historicizar a ascensão e a queda do mito do "paraíso tropical” atribuído ao Brasil, construído e refinado ao longo de séculos, realizamos o seminário "Ascensão e Queda do Paraíso Tropical", no SESC - Centro de Pesquisa e Formação de São Paulo e na Universidade Estadual de Campinas - UNICAMP, entre 20 de outubro e 12 de novembro de 2020. O evento reuniu intelectuais prestigiados de diversas universidades e áreas, entre historiadores, filósofos, sociólogos, psicanalistas, feministas, anarquistas, marxistas e pós-estruturalistas, que se destacam por suas instigantes e originais reflexões sobre o Brasil, ontem e hoje.

Apresentamos agora o resultado desse intenso trabalho de reflexão e discussão, publicando parte dos textos na Revista História: Questões e Debates, n. 69, vol. 2, da Universidade Federal do Paraná e da Associação Paranaense de História, e no livro a ser publicado em breve pela Editora Intermeios (SP). Iniciamos o dossiê da Revista com "Orbis minima pars est Europa: Humanismo erasmiano, respublica christiana e as raízes nãoeuropeias da Europa", em que o historiador Rui Luis Rodrigues revisita alguns textos de Erasmo de Roterdã, buscando compreender sua concepção de Europa, que, segundo ele, se formara a partir de múltiplas fontes, como "a Palestina dos evangelhos, a Síria helenizada de Luciano de Samósata ou a África de Agostinho e Orígenes".

Em "Fora do Paraíso", Jorge Coli analisa a produção de artistas que participam da construção do imaginário social do Brasil como "paraíso tropical" e, ao mesmo tempo, nos mostra que, se a grande maioria de artistas excluiu os negros em seus trabalhos artísticos, outros, como NicolasAntoine Taunay e Jean-Baptiste Debret, retrataram uma realidade cotidiana que nos permite conhecer de maneira mais precisa os povos nativos e seus costumes, no país.

Já os trabalhos de Edson Passetti e Gustavo Simões e de André Duarte e Maria Rita de Assis César apontam para a crítica desse imaginário, seja por anarquistas, no caso de "Solo do Paraíso", seja pelo Tropicalismo, no segundo texto, intitulado "Corpos, gêneros e sexualidades em disputa no Brasil contemporâneo: Bolsonarismo versus Tropicalismo”. Destacam o movimento estético-político que, cinquenta anos atrás, vislumbrava outros modos de interpretar o corpo, a sexualidade e o gênero, subvertendo as concepções retrógradas, misóginas e racistas dominantes. $\mathrm{O}$ que parecia página virada, no entanto, mostram os autores, vêm à tona, no presente, com as forças represadas dos grupos de direita e de extrema-direita na 
forma do bolsonarismo, que certamente se refere muito mais do que à política institucional. Nessa direção, destaca-se, ainda, o texto de Marilea de Almeida, "Racismo acadêmico e seus afetos", em que evidencia, a partir de uma triste experiência pessoal, a violência dos ataques racistas mesmo em meios universitários de esquerda.

Finalmente, Pedro Paulo Funari e Andrés Zarankin, em "Ditadura, Direitos Humanos e Arqueologia", nos mostram a importância política da Arqueologia da Repressão e da Resistência na América Latina, que, com suas escavações, testemunha praticamente a tortura e a eliminação dos corpos de opositores políticos, em momentos como a ditadura civil-militar de 1964-1985, no Brasil, para além de outras formas do exercício do controle autoritário dos corpos.

Encerramos este dossiê com o artigo "Condomínio fechado: paraíso cínico", de Tony Renato Hara e Gabriel José Pochapski, em que analisam a formação histórica do espaço do condomínio, tão conhecido na atualidade, que se pauta pela ideia do paraíso, mas que se transmuta na produção de subjetividades muito avessas à ética e à verdade, ao contrário do que pregavam os cínicos na Antiguidade.

Esperamos, com essas publicações, contribuir para que a crítica desse imaginário cultural tão nocivo e estigmatizador possa abrir espaço para a emergência de outros modos de pensar, inclusive dos que já existem em nosso repertório político, assim como para a invenção de outras contracondutas e para a criação de formas de existência mais horizontalizadas, libertárias, filóginas e solidárias. Fazendo coro às palavras do cineasta Karim Aïnouz, em entrevista realizada pelo Instituto Moreira Sales, em 2020:

"Acredito que essa pandemia deveria também anunciar o fim daquele mundo, não dá para 'voltar ao normal' porque o que vivíamos não era normal. É isso que desejo, que a ruína seja a ruína do sistema que vivemos hoje e que o futuro aponte para a superação do que está dado.”

Margareth Rago e Mauricio Pelegrini (Departamento de História - IFCH - UNICAMP) 
Esta edição da História Questões \& Debates ainda conta com as contribuições de três artigos, que compõem a sessão livre da Revista. Em "Desertificação em Gilbués - Piauí sob a ótica da História Ambiental", Dalton Melo Macambira e Jaíra Maria Alcobaça Gomes estudam a história da desertificação em Gilbués, localizado no sudoeste piauiense, a partir da teoria e da metodologia da história ambiental. Já Bernardo Borges Buarque de Hollanda, em "Aquém e além de O negro no futebol brasileiro: Uma releitura da obra do jornalista esportivo Mário Filho entre os anos 1940 e 1960", propõe uma nova leitura do livro principal do jornalista esportivo Mário Filho, $O$ negro no futebol brasileiro, de 1947. O último artigo, "Representações do desenvolvimento nas páginas da Série Realidade Brasileira: fascículos sobre a Amazônia", é escrito por Eduardo de Melo Salgueiro e tem como proposta principal analisar reportagens de suplementos especiais lançados pela Folha de S. Paulo em 1967 e 1968 sobre a Amazônia e as representações criadas sobre o "ideal de desenvolvimento e progresso" para a região.

Além disso, também serão publicadas três resenhas. Micael Alvino da Silva destaca, em "A usina de Itaipu e o Brasil rural", o livro Before the Flood, do historiador Jacob Blanc e publicado em 2019. Em "Um Raio-X da elite charqueadora pelotense do século XIX", Daniel de Souza Lemos ressalta a obra de 2016 Os Barões do Charque e suas fortunas, do historiador Jonas Vargas. Para finalizar, a resenha "Margareth Rago e 'As Marcas da Pantera': Por uma história filógina e libertária”, de Paloma Czapla aborda o livro de Margareth Rago, As marcas da pantera: percursos de uma historiadora, lançado em 2021. Agradecemos a contribuição das autoras e dos autores e desejamos a todas/os uma excelente leitura!

Priscila Piazentini Vieira (Editora da Revista) 